\title{
Effects of mulching materials on agronomic characteristics, pests of pepper (Capsicum annuum L.) and their natural enemies population
}

\author{
Mochiah, M.B. ${ }^{1 *}$, Baidoo, P.K. ${ }^{2}$, Acheampong, G. $^{2}$ \\ ${ }^{1}$ Entomology Section, Crops Research Institute, P. O Box 3785, Kumasi, Ghana \\ ${ }^{2}$ Department of Theoretical and Applied Biology, Kwame Nkrumah University of Science and \\ Technology, Kumasi, Ghana \\ *Corresponding author e-mail: mochiah63@yahoo.com
}

\begin{abstract}
The trial was to study the effect of different mulching materials on agronomic characteristics, pests and their subsequent effect on the natural enemies of the pests of pepper (Capsicum annuum). A field experiment was conducted at the Department of Theoretical and Applied Biology, Kwame Nkrumah University of Science and Technology (KNUST), between December, 2010 and March, 2011. The mulching materials used were (1) straw mulch, (2) plastic mulch and (3) live-mulch of cowpea plant. The experimental field contained fifteen plots using a randomised complete block design in three replications. Parameters measured were pests of Capsicum annuum, some natural enemies of the pests, days to $50 \%$ flowering, plant height, plant girth, damage caused and yield assessment which included damaged fruits caused by the pests, number of fruits, fruit weight (in grams), and percentage increase in fruit yield. Plant height was seemingly highest under straw mulched soils. Straw mulch also flowered early as compared to the live-mulch of cowpea and plastic mulch but the margin was narrow. None of the mulches exhibited higher pest suppression ability over the other. However, Straw mulch had apparently larger population of natural enemies than the other treatments. Damaged fruits in the three mulching materials did not differ significantly. Control plot soils had significantly $(P<0.05)$ higher temperatures than the mulched soils. The results indicated that straw mulch enhanced plant height and increased fruit number and percentage yield whilst live-mulch of cowpea and plastic mulch reduced plant height, fruit number and percentage yield. Data generated in this study have shown that cowpea mulch may be more effective in suppressing pest populations of pepper but straw mulch may provide a better refuge for the natural enemies and should be recommended as an integral option for pest management in pepper production.
\end{abstract}

Key words: Mulching materials, Capsicum annuum, pests, natural enemies, soil temperatures

\section{INTRODUCTION}

Pepper (Capsicum annuum L.) belongs to the family Solanaceae and has always been one of the most important vegetables in West Africa and the world at large. Apart from its edible properties, pepper has many uses, some of which include provision of vitamins (Rozin and Schiller, 1980), effective in crop defence against elephants which has reduced the physical confrontation between people and elephants (Perry, 2007). The "hot" sensation in pepper is attributed to the ingredient capsaicin (8-methyl- $N$ vanillyl-6-nonenamide) (Chilli Pepper Glossary, 2008) which is the primary ingredient in the spray used as an irritant weapon (Johnson, 2007).
Very key among the problems associated with the growth of pepper is the occurrence of pests which usually result in the outbreak of many diseases. Generally, insect pests which attack the leaves, stem and fruits of $C$. annuum include Tetranynchus urticae (spider mites), Aphis gossypii (aphids), Bemisia tabaci (Whiteflies), Epitrix cucumeris (Flea beetles), Thrips tabaci (Thrips), Pseudaletia unipuncta (Army worm) and Ostrinia nubilalis (corn borers) (Nielsen, 1997; Tom, 2002; Redmond, 2008; Boucher, 2009). These pests greatly affect the growth of pepper and thus reduce yield considerably. In most cases, many farmers resort to the use of chemical pesticides in combating the activities of these pests on their vegetable farms. Does the use of chemical pesticides provide the antidote to these pests? It is an 
undeniable fact that pesticides contribute greatly in reducing the numbers and effects of pests on the crop, but their use is not without problems.

Apart from the high cost of these chemicals and the health hazards which they pose to farmers, they undoubtedly destroy natural enemies or predators that may kill the pest population (Gilden et al., 2010). The natural enemies of these pests assist in keeping the high population of the pests in check to prevent them from reaching levels where they can cause heavy economic losses to farmers.

Natural enemies or beneficial insects such as Ladybird beetles, spiders and predatory arthropod such as centipedes occur abundantly in cropland and provide a significant amount of control to some crop pests. The action of natural enemies is a form of biological control (Mahr et al., 2008). The benefits and importance of mulching in modern agriculture respective to the type of material used have been stressed by many authors (Lu et al., 1994; Tisdale et al., 1995; Hutchinson and McGiffen, 1999; Johnson et al., 2004; Agropages, 2009; Kluepfel and Bob, 2009).

Cultural control measures comprise using mulching materials such as Aluminium foils (repel Aphis gossypii), isolating and choosing varieties recommended for a particular area and rotating the crops (Agropages, 2009; Mahr et al., 2008; Sally, 2007). Combination of these control measures is also applicable. This is referred to as Integrated Pest Management (IPM) (Agropages, 2009). Redmond (2008) contended that when some of these cultural measures are properly and extensively employed, IPM might reduce pesticide use by as much as $50 \%$, while at the same time improve pest control.

Enhancing the population of natural enemies to manage pests of pepper can be easily and effectively supplemented with cultural methods such as mulching but the suitable material could be critical and must be carefully-chosen. Assessment of some agronomic characteristics and pest suppression potential of the mulching materials for pest management in pepper production are discussed.

\section{MATERIALS AND METHODS}

Study area: The study was carried out on a large stretch of experimental field behind the Department of Theoretical and Applied Biology (TAB), KNUST in Kumasi, Ashanti Region. The study was specifically carried out in the North block part of the land. The topography of the land is slightly undulating. The type of soil in this area was observed to be loamy with moderate porosity, hence moderate water retention ability. The site has ferric acrisols as the dominant soil type.

Soil samples were taken from the field to the Faculty of Renewable Natural Resources Laboratory where the $\mathrm{pH}$ of the soil was determined to be 7.2, using a $\mathrm{pH}$ metre. Generally, the top soil is about $0.3 \mathrm{~m}$ deep and contains less gravel. The average annual relative humidity for the period from November, 2010 to March 2011 ranged between $76.6 \%$ and $69.3 \%$. Average annual precipitation $(\mathrm{mm})$ at the study area ranged from 72.78 to 166.58 with average annual maximum and minimum air temperatures ranging from 31.45 to 34.18 and 19.78 to 23.24 respectively (Hamenoo, 2010).

Land preparation and transplanting of the seedlings: The land was cleared and root stumps removed after weeding prior to sowing of seeds. Ploughing and harrowing were performed on the land before beds were made. The pepper seedlings were transplanted on the $18^{\text {th }}$ January, 2011 to the main experimental field. Uniform seedlings of height $15 \mathrm{~cm}$ with 3 to 5 leaves were transplanted. The pepper variety used was Shito Adope with planting distance of $70 \mathrm{~cm} \times 30 \mathrm{~cm}$ on plots that measured $4.2 \mathrm{~m} \times 4.0$ $\mathrm{m}$. The transplanted seedlings were watered right after transplanting. They were also watered frequently on subsequent days, at least twice a day (early morning and evening), depending on the soil moisture content. Manual hoeing was done every fortnight to control weeds. No fertilizer was applied to the various plots.

Design and application of treatments: The experimental design was a Randomized Complete Block Design (RCBD) consisting of five treatments replicated three times. The treatments were Straw mulch, Plastic (black-coloured) mulch, Live-mulch of cowpea plants, chemical insecticide (lamdacyhalothrin, with the trade name as 'PAWA') and No mulch (control). These treatments were applied one week after transplanting of the seedlings. The application dosage for lamda-cyhalothrin was 36 $\mathrm{ml} / 15 \mathrm{l}$ of water.

Data collection: Collection of data commenced five (5) weeks after transplanting (5WAT) and continued at weekly interval till harvest. The following data were collected: Pests populations, natural enemies of the various pests, soil temperatures (both at the surface and to $5-\mathrm{cm}$ depth), plant growth parameters, 
damage caused and yield assessment which included damaged fruits caused by the pests, number of fruits, fruit weight (in grams), and percentage increase in yield. Mean percentage increase in fruit yield was determined using the method as follows:

Mean \% increase in fruit yield $=\frac{X_{2}-X_{1}}{X_{2}} \times 100 \%$

Where, $\quad X_{1}=$ Unprotected yield and $X_{2}=$ Protected (with mulch) yield.

Data analysis: Data obtained were subjected to analysis of variance and means of numbers of insects counts, soil temperature values, plant growth parameters and fruit weight were compared using PROC GLM; SAS Institute, 2004/2005 (Version 9). When significant differences were obtained $(P<0.05)$, means were separated with Student-Newman Keul's (SNK) test.

\section{RESULTS}

Pests of Capsicum annuum: Major insect pests observed on the $C$. annuum crop during the study period were aphids (Aphis gossypii) mostly located on the under surface of leaves, either singly or in colonies, thrips (Thrips tabaci) and white flies (Bemisia tabaci (Genn.)), cotton strainers (Dysdercus superstitiosus (F.)) and variegated grasshoppers (Zonocerus variegatus).

For A. gossypii, there were non-significant differences among the mulched plots but differed from the chemical insecticide plots. However, mean populations of $A$. gossypii from all the mulch plots as well as the chemical insecticide plots differed significantly from the control (Table 1). The largest mean number (3.3) of $A$. gossypii was recorded on the control plots whilst the chemical insecticidesprayed plots recorded the least mean number of Aphids (0.5) (Table 1).

Similarly results from the study on populations of $T$. tabaci and B. tabaci indicated that there were significant differences between the mulched plots and the chemical insecticide-sprayed plots (Table 1) but all these plots were significantly different when the mean numbers of $T$. tabaci and $B$. tabaci from the control plot were compared $(P=0.0001)$. T. tabaci numbers ranged from a mean of 0.3 on the chemical insecticide-sprayed plot to 1.7 on the control plots (Table 1). B. tabaci numbers were largest on the control plots (2.6) whilst the chemical insecticidetreated plots recorded least (Table 1).

Except the chemical insecticide plots, the mean numbers for $D$. superstitiosus and $Z$. variegatus, were not significantly different among the mulched plots and the control plots (Table 1). The largest numbers of $D$. superstitiosus and $Z$. variegatus were 3.2 and 3.4 respectively and these were recorded from the control plots whilst the least were 0.9 and 1.1 were recorded from the chemical insecticide plots (Table 1).

Natural enemies of Pests of $C$. annuum: Generally, the natural enemies observed and identified were Scutigera coleoptrata (centipede), Argiope aurantia (garden spider) and Cheilomenes sp. (ladybird beetle). Cheilomenes sp was observed feeding on the pests identified as aphids.

Results from the study on the mean numbers for $S$. coleoptrata were not significantly different among the mulched plots, the chemical insecticide-sprayed plots as well as the control plot (Table 2). However, the largest number of $S$. coleoptrata (1.0) was recorded from the Straw mulch plots whilst the least $(0.4)$ was recorded from the chemical insecticide plots (Table 2).

Mean numbers of $A$. aurantia and Cheilomenes sp indicated that there were no significant differences among the mulched plots. However, they differed significantly from the chemical insecticide-sprayed plots as well as the control plots $(P=0.0001)$. The control plots recorded the mean largest numbers of A. aurantia (1.7) and Cheilomenes sp (1.9). However, plots sprayed with chemical insecticide recorded the least (0.6) numbers of $A$. aurentia and Cheiolmenes sp (Table 2).

\section{Growth parameters and yield of Capsicum annuum}

Plant height and girth: No significant differences were observed among the mulched plots, the chemical insecticide-sprayed plots as well as the control plots for both plant heights $(P=0.6843)$ and girths $(P=0.3179)$ (Table 3$)$. Plant height was tallest on straw mulch plots, with a mean height of $25.0 \mathrm{~cm}$ followed by the control with a mean height of $24.9 \mathrm{~cm}$ (Table 3) whilst live-mulch of cowpea plants recorded the least of $23.8 \mathrm{~cm}$. However, live mulch of cowpea and the chemical insecticide plots recorded the largest plant girth of $1.2 \mathrm{~cm}$ each. The least plant girth of $1.0 \mathrm{~cm}$ was measured in plastic mulch treatment. 
Agric. Biol. J. N. Am., 2012, 3(6): 253-261

Table 1: Mean populations of insect pests on pepper (Capsicum annuum) grown under different mulching materials Mean $\pm(\mathrm{SE})$ number of insect pests /plant

\begin{tabular}{llllll}
\hline Mulch type & $\begin{array}{l}\text { Aphis } \\
\text { Gossypii }\end{array}$ & $\begin{array}{l}\text { Thrips } \\
\text { tabaci }\end{array}$ & $\begin{array}{l}\text { Bemisia } \\
\text { tabaci }\end{array}$ & $\begin{array}{l}\text { Dysdercus } \\
\text { superstitiosus }\end{array}$ & $\begin{array}{c}\text { Zonocerus } \\
\text { variegatus }\end{array}$ \\
\hline Straw & $1.9 \pm 0.3^{\mathrm{b}}$ & $0.7 \pm 0.2^{\mathrm{b}}$ & $1.2 \pm 0.3^{\mathrm{b}}$ & $2.6 \pm 0.2^{\mathrm{a}}$ & $2.9 \pm 0.2^{\mathrm{a}}$ \\
Plastic & $1.7 \pm 0.3^{\mathrm{b}}$ & $0.6 \pm 0.2^{\mathrm{b}}$ & $1.1 \pm 0.3^{\mathrm{b}}$ & $2.2 \pm 0.3^{\mathrm{a}}$ & $2.7^{\mathrm{a}} \pm .1^{\mathrm{a}}$ \\
Live cowpea & $1.2 \pm 0.4^{\mathrm{b}}$ & $1.1 \pm 0.2^{\mathrm{b}}$ & $1.0 \pm 0.2^{\mathrm{b}}$ & $2.4 \pm 0.2^{\mathrm{a}}$ & $2.5 \pm 0.3^{\mathrm{a}}$ \\
PAWA & $0.5 \pm 0.1^{\mathrm{c}}$ & $0.3 \pm 0.1^{\mathrm{c}}$ & $0.5 \pm 0.1^{\mathrm{c}}$ & $0.9 \pm 0.1^{\mathrm{b}}$ & $1.1 \pm 0.2^{\mathrm{b}}$ \\
Control & $3.3 \pm 0.3^{\mathrm{a}}$ & $1.7 \pm 0.3^{\mathrm{a}}$ & $2.6 \pm 0.3^{\mathrm{a}}$ & $3.2 \pm 0.2^{\mathrm{a}}$ & $3.4 \pm 0.1^{\mathrm{a}}$ \\
\hline $\mathrm{P}$ & 0.0038 & 0.0079 & & & \\
\hline
\end{tabular}

Means with the same letters in the same column are not significantly different at $\mathrm{P}=0.05$.

Table 2: Mean populations of predators on pepper (Capsicum annuum) grown under different mulching materials

\begin{tabular}{llll}
\hline \multicolumn{4}{c}{ Mean $\pm(\mathrm{SE})$ number of predators /plant } \\
\hline Mulch type & $\begin{array}{l}\text { Scutigera } \\
\text { coleoptrata }\end{array}$ & $\begin{array}{l}\text { Argiope } \\
\text { aurantia }\end{array}$ & $\begin{array}{l}\text { Cheilomenes } \\
\text { sp. }\end{array}$ \\
\hline Straw & $1.0 \pm 0.2^{\mathrm{a}}$ & $1.6 \pm 0.2^{\mathrm{a}}$ & $1.8 \pm 0.3 \mathrm{a}$ \\
Plastic & $0.5 \pm 0.3^{\mathrm{a}}$ & $1.3 \pm 0.2^{\mathrm{a}}$ & $1.3 \pm 0.2^{\mathrm{a}}$ \\
Live cowpea & $0.7 \pm 0.2^{\mathrm{a}}$ & $1.0 \pm 0.1^{\mathrm{a}}$ & $1.2 \pm 0.2^{\mathrm{a}}$ \\
PAWA & $0.4 \pm 0.1^{\mathrm{a}}$ & $0.5 \pm 0.2^{\mathrm{b}}$ & $0.6 \pm 0.1^{\mathrm{b}}$ \\
Control & $0.8 \pm 0.1^{\mathrm{a}}$ & $1.7 \pm 0.3^{\mathrm{a}}$ & $1.9 \pm 0.2^{\mathrm{a}}$ \\
\hline $\mathrm{P}$ & 0.6038 & 0.0001 & 0.0001
\end{tabular}

Means with the same letters in the same column are not significantly different at $\mathrm{P}=0.05$.

Days to $50 \%$ flowering: Similarly no significant differences were observed among the mulched plots, the chemical insecticide-sprayed plots as well as the control plots for Days to $50 \%$ flowering $(P=0.7148)$. Mean number of days to $50 \%$ flowering of pepper from this study ranged from 54.0 days to 57.0 days (Table 3).

Damaged fruits: No significant differences were observed among the mulched plots and the chemical insecticide-sprayed plots for damaged fruits, but all the treatments were significantly different when compared with control $(P=0.0007)$. Thus more fruits were damaged on the control plants (5.1) than the plants which were mulched. Damaged fruits were least on the plots sprayed with chemical insecticide (Table 3).
Number of Fruits: The mean number of fruits recorded from plastic mulched plots was not significantly different from the live cowpea-mulched plots. Again, the mean number of fruits on straw mulched plots was not significantly different from plastic-mulched plots (Table 3). Chemical insecticidesprayed plots recorded the largest number of pepper fruits (23.9) followed by plots treated with Straw mulch (21.8) whilst the control plots recorded the least number of fruits (11.4).

Fruit Weight: There was a significant difference between the mean fruit weight of pepper from straw much and the live cowpea mulch plots but not significantly different from that of chemical insecticide-sprayed plots (Table 3). The mean fruit weight ranged from $3.8 \mathrm{~g}$ on control plots to $7.7 \mathrm{~g}$ on Chemical insecticide treatment plots. Plastic mulch 
and the live cowpea mulch plots recorded the same mean fruit weight of $4.8 \mathrm{~g}$.

Percentage increase in fruit Yield: Compared to the control plots, chemical insecticide application, the straw, plastic and cowpea mulch treatments, significantly $(P=0.0001)$ increased the fruit yield by $43 \%, 40 \%, 23 \%$ and $22 \%$ respectively. However, there was no significant difference in fruit weight between straw mulch plots and chemical insecticidesprayed plots (Table 3).

Soil temperature: For surface soils, control plot soils had significantly $(P<0.05)$ higher temperatures than the mulched soils. As shown in Table 4, control soils i.e. unmulched and PAWA had the highest mean surface soil temperature of $33.9^{\circ} \mathrm{C}$ and $33.8^{\circ} \mathrm{C}$ respectively. Next were plastic mulch $\left(31.7^{\circ} \mathrm{C}\right)$, live cowpea mulch $\left(31.5^{\circ} \mathrm{C}\right)$ and lastly, straw mulch $\left(30.2^{0} \mathrm{C}\right)$. Similar temperature observations were made for mulch at 5-cm soil depth.

\section{DISCUSSION}

Impact of mulching materials on the mean score and the number of pests: In this study $A$. gossypii first appeared at the seedling stage, sucking the plant sap, leaving the leaves curled and wrinkled which were mostly observed on the control plots with similar finding made by Brust (2008). Results from this study and studies by Saucke et al. (2009) have indicated that mulches have no significant effect on aphid colonisation. This may be due to fact that straw and other mulching materials used in this study probably do not exhibit pest-repellent properties. The synthetic insecticide was very effective in controlling the aphid population. This may be due to the systemic nature of the insecticide as evidenced in a similar study by Koch and Lawson (1996). The mulching materials used in this study though lagged behind the synthetic insecticide caused a significant reduction in aphid population compared with the control and could be considered as an integral component of pest management practice for organic production of pepper especially the cowpea mulch.

Generally, pest populations of T. tabaci, B. tabaci, D. superstitiosus and Z. variegatus in this present study were suppressed with the use of different mulch materials. This finding is supported by Johnson et al. (2004) that pest populations were relatively higher in plots that were mulched with straw compared to the other treatments, excluding the control plots (Table 2). In a related study by Madhiyazhagan (2005) mulches were reported to cause no reduction in levels of pest infestations but were able to enhance plant tolerance to pests and also reduced subsequent plant mortality compared to control plants.

Mulching materials and natural enemies: In the present study, the populations of natural enemies mainly Cheilomenes sp and A. aurantia were similar on both the mulch treated plots and the control, suggesting that the mulch did not have any adverse effect on these natural enemies compared to the chemical insecticide which was not selective in its action, but reduced the insect population in the field including their natural enemies. As biological control agents, any decrease in their population can adversely affect the pests they assist in controlling on the crop plant. Cheilomenes sp. is a natural enemy of $A$. gossypii, B. tabaci and T. tabaci as reported in earlier studies by Mochiah et al. (2011a; 2011b). A. aurantia population also showed the same trend as Cheilomenes sp. and $S$. coleoptrata, hence the mulching materials were also effective as compared to the control in conserving the population of natural enemies. Studies by Johnson et al. (2004) revealed that straw mulch could impact on arthropod pest and predator populations. Our studies suggest that insect pests may be negatively impacted, whereas natural enemies' populations may be enhanced. Straw mulch on potatoes has been shown to reduce Colorado potato beetle, Leptinotarsa decemlineata (Say) populations in other studies, generally associated with increases in predator populations (Zehnder and Hough-Goldstein 1990; Stoner 1993, 1997; Brust, 1994).

Mulching materials on the growth parameters and yield of $\boldsymbol{C}$. annuum: The growth parameters also described as 'vegetative and reproductive traits' of the plant (Aboagye and Bennett-Lartey, 2004) in this study included plant height, plant girth and days to $50 \%$ flowering. None of the above parameters was significantly different among the treatments including the control. This probably suggests inherent expression of traits that were not significantly affected by the treatments as again indicated by Aboagye and Bennett-Lartey (2004). Results from this study have shown that the straw mulch enhanced the growth of C. annuum. This result agrees with previous studies which showed the superiority of straw mulched plants over the unmulched plants (Opara-Nadi, 1993; Hudu et al., 2002; Awodoyin and Ogunyemi, 2005). Again, this study supports previous report by Hochmuth et al., (2001), that Capsicum annuum could invariably benefit from straw mulching. 
Agric. Biol. J. N. Am., 2012, 3(6): 253-261

Table 3: Mean growth parameters and yield of pepper (Capsicum annuum) grown under different mulching materials

\begin{tabular}{|c|c|c|c|c|c|c|c|}
\hline \multirow[b]{2}{*}{ Mulch type } & \multicolumn{6}{|c|}{ Mean $\pm(\mathrm{SE})$ growth parameters and yield /plot } & \multirow[b]{2}{*}{$\begin{array}{l}\% \text { increase } \\
\text { in yield }\end{array}$} \\
\hline & $\begin{array}{l}\text { Plant } \\
\text { Height }(\mathrm{cm})\end{array}$ & $\begin{array}{l}\text { Plant } \\
\text { girth }(\mathrm{cm})\end{array}$ & $\begin{array}{l}\text { Days to } 50 \% \\
\text { flowering }\end{array}$ & $\begin{array}{l}\text { Damaged } \\
\text { fruits }\end{array}$ & $\begin{array}{l}\text { No. of } \\
\text { fruits }\end{array}$ & $\begin{array}{c}\text { Fruit } \\
\text { weight }(g)\end{array}$ & \\
\hline Straw & $25.0 \pm 2.3$ a & $1.1 \pm 0.1 \mathrm{a}$ & $55.7 \pm 1.9$ a & $1.7 \pm 0.2 \mathrm{~b}$ & $21.8 \pm 3.9$ a & $6.6 \pm 0.9 \mathrm{ab}$ & $40.0 \pm 5.5^{a}$ \\
\hline Plastic & $24.4 \pm 1.0 \mathrm{a}$ & $1.0 \pm 0.1 \mathrm{a}$ & $56.0 \pm 0.6$ a & $1.9 \pm 0.2 b$ & $15.6 \pm 1.7^{a_{b}}$ & $4.8 \pm 0.5 \mathrm{bc}$ & $22.6 \pm 5.2$ b \\
\hline PAWA & $24.3 \pm 3.3$ a & $1.2 \pm 0.1$ a & $54.0 \pm 2.1 \mathrm{a}$ & $1.4 \pm 0.2 \mathrm{~b}$ & $23.9 \pm 1.7^{a}$ & $7.7 \pm 0.7$ a & $43.0 \pm 4.3$ a \\
\hline Control & $24.9 \pm 2.5$ a & $1.1 \pm 0.0 \mathrm{a}$ & $55.0 \pm 1.2$ a & $5.1 \pm 0.8$ a & $11.4 \pm 1.3 \mathrm{~b}$ & $3.8 \pm 0.3 c$ & - \\
\hline $\bar{P}$ & 0.6843 & 0.3179 & 0.7148 & 0.0007 & 0.0001 & 0.0002 & 0.0008 \\
\hline
\end{tabular}

Means with the same letters in the same column are not significantly different at $P=0.05$.

Table 4: Mean soil temperatures $\left({ }^{\circ} \mathrm{C}\right.$ ) of pepper (Capsicum annuum) grown under different mulching materials

\begin{tabular}{lll}
\hline \multicolumn{2}{l}{ Mean $\pm(\mathrm{SE})$ soil temperature /plot } \\
\hline Mulch type & Soil surface & Soil depth (5-cm) \\
\hline Straw & $30.2 \pm 0.2^{\mathrm{b}}$ & $27.1 \pm 0.2^{\mathrm{b}}$ \\
Plastic & $31.7 \pm 0.3^{\mathrm{b}}$ & $29.6 \pm 0.2^{\mathrm{b}}$ \\
Live cowpea & $31.5 \pm 0.2^{\mathrm{b}}$ & $28.4 \pm 0.2^{\mathrm{b}}$ \\
PAWA & $33.9 \pm 0.1^{\mathrm{a}}$ & $32.1 \pm 0.1^{\mathrm{a}}$ \\
Control & $33.8 \pm 0.2^{\mathrm{a}}$ & $32.0 \pm 0.1^{\mathrm{a}}$ \\
\hline P & & 0.0042 \\
\hline
\end{tabular}

Means with the same letters in the same column are not significantly different at $P=0.05$. 
Damage assessment and yield: In terms of damage assessment, there was no significant difference in the mean number of fruits that were damaged on the mulched plots. With the exception of chemical insecticide, all the other treatments had a larger number of damaged fruits than straw mulch treatment. Damage caused by the pests included marked, wrinkled plant (caused by Aphis gossypii); black, sooty mould that grew on the honeydew on the leaves (sticky residue) preventing photosynthesis (caused by $B$. tabaci); unattractive fruits; and holes on some fruits.

The prevention of direct contact of solar radiation with the soil by the mulches explains the low soil temperature compared with the unmulched soils. Mulch did not increase soil temperatures at surfaceand $5-\mathrm{cm}$ depth, in agreement with a previous investigation (Mtshali, 1984) where it was indicated that mulch protected the soil from extreme heat, as the unmulched soil did in this investigation. Our results agreed with previous reports (Mtshali, 1984; Bell et al., 1960) that with the use of mulch, temperature was more constant than without the use of mulch. The results of this investigation were also in agreement with another finding (Buerkert et al., 2000) that noted reduced soil temperatures under mulch.

Mean number of fruits, mean fruit weight and percentage yield are the principal components in determining the final yield of Capsicum annuum (Aboagye and Bennett-Lartey, 2004). These parameters were largest in straw mulched plots as compared to the other mulch treatments. This observation in the present study supports the previous findings by Dzomeku et al. (2009). One of the factors that contribute to the proper growth of a particular plant species is the availability of air in the soil. Though we did not assess the available air trapped by the various mulch materials it is speculated that plots with plastic mulch treatment had very low amount of atmospheric air trapped into the soil as earlier reported by Scutte (1999). This might have contributed directly or indirectly to the relatively low fruit yield from plots treated with plastic mulch.

The increased growth and fruit yield of $C$. annuum under the straw mulch may be explained by the conservation of moisture and reduction of temperature in the top soil, and suppression of weed growth. The latter resulted in reduced weed-crop competition. Rose (1996) reported that straw mulches have high carbon to nitrogen ratio, slowing down the rate of decomposition and providing a relatively longer period of cover on the soil. Hochmuth et al. (2001) also reported that the primary objectives of mulching are weed control, soil moisture conservation and temperature modification.

Though we did not study moisture content, it is speculated that straw mulch might have conserved more soil moisture and could be probably due to the ability of straw to protect intense heating of the soil and, therefore, keeping the microclimate of the soil cool. This study shares the same view with Ossom and Matsenjwa (2007) that straw mulch, unlike the other mulches and the control, was able to increase the infiltration rate of rain or irrigation water, whereas in the other mulches, the water might not have properly infiltrated into the soil and the water could have been left on the surface of the mulch (as was observed in plastic mulches) and could have evaporated as the sun's heat increased. Again, it was possible that straw mulch could have absorbed dew in the early mornings and such moisture could move by diffusion gradient to the drier soil beneath. The findings of this study were consistent with previous findings (Mtshali, 1984) in which it was shown that trash (such as grass mulch) improved the moisture regime of the soil. It was also previously shown that organic mulch could help retain soil moisture, avoid or prevent soil desiccation and improve plant survival (Hummell and McKay, 2006). It was further explained (Walker and Mclaughlin, 1989) that improve plant performance was also attributable largely to improved water relations resulting from diminished soil surface evaporation and elimination of transpirational losses from competing vegetation. All these important processes could have enhanced the growth and per cent yield of C. annuum.

\section{CONCLUSION AND RECOMMENDATION}

This study has explored the possibility that though mulches might control insect pests the type of material should be taken into consideration. Data generated in this study have shown that cowpea mulch may be more effective in suppressing pest populations of pepper but straw mulch may provide a better refuge for the natural enemies and should be recommended as an integral option for pest management in pepper production. More studies should be conducted to establish the relationship of mulches to insect pest control in general.

\section{ACKNOWLEDGEMENTS}

We thank Messrs Augustine Agyekum and Anthony Gyimah for assistance with data collection and 
compilation; and Dr. M. Owusu-Akyaw for his inspiration and technical support to bring the manuscript in this form. This study was supported by a collaborative project between CSIR-Crops Research Institute and Kwame Nkrumah University of Science and Technology.

\section{REFERENCES}

Aboagye, L. M., Bennett-Lartey, S. O. (2004). Characterization and Preliminary evaluation of Pepper (Capsicum sp.) Germplasm collected from Ghana. Journal of the Ghana Science Association. Vol. 6. № 1.pp.

Agropages. (2009). Pest control measures: An adequate solution for controlling pest population. Viewed 27 January 2011. http:www.agropages.com/pdt.html.

Awodoyin, R. O., Ogunyemi, S. (2005). Use of sicklepod, Senna obtusifolia (L.) Irwin and Barneby, as mulch interplant in cayenne pepper, Capsicum frutescens $\mathrm{L}$., production. Emirate Journal of Agricultural Science 17(1): 10-22.

Azhar, A. F., Sreeramu, B. S., Srinivasappa, K. N. (2005). 'Cultivation of Spice Crops', Universities Press, pp. 336.

Bell, G. D. H., Evans, Hamond, R. E. J., Keen, B., Russell, J. E., Schofield, R. K., Yates, F. (Eds.), (1960). Effect of black polythene mulch on soil microclimate and temperature and nitrate level. Agron. J., 52: 307-309.

Boucher, T. J. (2009). 'Vegetable Integrated pest management', University of Connecticut Cooperative Extension System, 24 Hyde Ave, Vernon, CT 06066, (860) 875-3331.

Brust, G. E. (2008). University of Maryland. New article June 22 on Early Season Thrips and Aphid populations. pp.

Brust, G. E. (1994). Natural enemies in straw-mulch reduce Colorado potato beetle populations and damage in potato. Biol. Control. 4: 163-169.

Buerkert, A., A., Bationo, Dossa, K. (2000). Mechanisms of residue mulch-induced cereal growth increases in West Africa. Soil Sci. Soc. Am. J., 64: 346-358.

Chilli Pepper Glossary. (2008). TheNibble Online Specialty Food Magazine. viewed 04 November 2010, http://www.thenibble.com/reviews/main/salts/scoville.a sp.

Dzomeku, I. K., Mahunu, G. K., Bayorbor, T. B., ObengDanso, P. (2009). Effects of mulching on weed control and yield of hot pepper and tomato in the Guinea Savannah zone. Ghana Journal of Horticulture. Vol. 7 pp. 53-62.
Gilden, R. C., Huffling, K., Sattler, B. (2010). 'Pesticides and health risks'. J. Obstet. Gynecol.Neonatal Nurs. 39(1), pp. $103-110$.

Hamenoo, S. V. Q. (2010). Influence of Land Preparation on Asontem Cowpea Growth and Yield. BSc. Thesis submitted to the Department of Agricultural Engineering, Kwame Nkrumah University of Science and Technology. Kumasi. Pp. 21-23.

Hochmuth, G. J., Hochmuth, R. C., Olson, S. M. (2001). Polyethylene Mulching for Early Vegetable Production in North Florida. University of Florida/Institute of Food and Agricultural Sciences (UF/IFAS), Florida A \& M University Cooperative Exten-sion Programm. http:/edis.ifas.ufl.edu

Hudu, A. I., Futuless, K. N., Gworgwor, N. A. (2002). Effects of mulching intensity on the growth and yield of irrigated tomato (Lycopersicon esculentum Mill.) and weed infestation in semi-arid zone of Nigeria. Journal of Sustainable Agriculture 21:37-45.

Hummell, C., McKay, E. (2006). Maximizing soil moisture through mulch and slash applications. Oregon State University, Oregon, USA. pp.

Hutchinson, C. M., McGiffen, M. E. Jr. (1999). Cowpea Cover Crop Mulch for Weed Control in Desert Pepper Production, Proceedings of the California Weed Science Society Volume 51.pp.

Johnson, J. M., Hough-Goldstein, J. A., Vangessel, M. J. (2004). Effects of straw mulch on pest insects, predators, and weeds in watermelons and potatoes, Entomological Society of America, Lanham, vol. 33, № 6, pp. 1632-1643.

Johnson, W. (2007). "Final report on the safety assessment of Capsicum annuum extract, Capsicum annuum fruit extract, Capsicum annuum resin, Capsicum annuum fruit powder, Capsicum frutescens fruit, Capsicum frutescens fruit extract, Capsicum frutescens resin, and Capsaicin". Int. J. Toxicol. 26 Suppl 1: 3-106.

Kluepfel, M., Bob, P. (2009). Extension Consumer Horticulture, Clemson University. South Carolina, USA.

Koch, H. P., Lawson, L. D. (1996). Garlic, the science and therapeutic application of Allium sativum and related species, $2^{\text {nd }}$ edition. Williams \& Wilkerns ISBN 0-68318147-5.

Lu, N., Edwards, J. H., Walker, R. H., Bannon, J. S. (1994). 'Newsprint and Nitrogen Source Interaction on Corn Growth and Grain Yield', Proceedings of the Second Conference, Orlando, FL.

Madhiyazhagan, R. (2005). Global theme on agroecosystems. ww.gt.agrosystems.html.06/02/2006

Mahr, D. L., Whitaker, P., Ridgway, N. M. (2008). 'Biological control of insects and mites: An introduction to beneficial natural enemies and their use in pest 
management'. University of Wisconsin Cooperative Extension Publication A3842.

Mochiah, M. B., Baidoo, P. K., Owusu-Akyaw, M. (2011). Influence of different nutrient applications on insect populations and damage to cabbage. Journal of Applied Biosciences 38: 2564 - 2572.

Mochiah, M. B., Banful, B., Fening, K. O., Amoabeng, B. W., Offei Bonsu, K., Ekyem, S. O., Braimah, H., Owusu-Akyaw, M. (2011). Botanicals for the management of insect pests in organic vegetable production. Journal of Entomology and Nematology Vol. 3 (8): 85-97.

Mtshali, T. X. F. (1984). The measurement of available water in the soil under different tillage regimes with emphasis on mulching. Unpublished B.Sc. Dissertation, University of Swaziland, Luyengo. Pp.

Nielsen, G. R. (1997). Pepper pests. 'Plant and Soil Science Department'. University of Vermont, USA. Pp.

Opara-Nadi, O. A. (1993). Effect of elephant grass and plastic mulch on soil properties and cowpea yield. In: Mulongoy, K. and Merckx. R. (eds.), Soil Organic Matter Dynamics and Sustainability of Tropical Agriculture. John Wiley \& Sons, New York. P. 351-360.

Ossom, E. M., Matsenjwa, V. N. (2007). Influence of Mulch on Agronomic Characteristics, Soil Properties, Diseases and Insect Pest Infestation of Dry Bean (Phaseolus vulgaris L.) In Swaziland. World Journal of Agricultural Sciences 3 (6):696-703.

Perry, L. (2007). 'Starch fossils and the domestication and dispersal of chili peppers (Capsicum spp.) in the Americas', Science 315, pp. 986-988.

Redmond, W. A. (2008). Aphids, Spiders and Whiteflies, Microsoft Corporation. pp.

Rose, M. A. (1996). Mulching Landscape |Plants. Ohio State University Extension Fact Sheet, HYG-1083-96. $5 \mathrm{pp}$.
Rozin, P., Schiller, D. (1980). 'The nature and acquisition of a preference for chili pepper by humans', Motivation and Emotion 4 (1), pp. 77-101.

Sally, O. (2007). Natural organic pest control, insecticide and pesticide using herbs and natural methods.

SAS Institute Inc. (2005). SAS/STAT User's Guide Version 6, Fourth Edition Vol. 1, SAS Institute, Cary N. C., 943 pp.

Saucke, H., Juergens, M., Döring, T., Fittje, S., Lesemann, D., Vetten, H. (2009). Effect of sowing date and straw mulch on virus incidence and aphid infestation in organically grown faba beans (Vicia faba). Annals of Applied Biology, 154: 239-250.

Schutte, R. (1999). Feed the soil not the plant. Introduction to organic gardening. pp. 8.

Stoner, K. A. (1993). Effects of straw and leaf mulches and trickle irrigation on the abundance of Colorado potato beetles (Coleoptera: Chrysomelidae) on potato in Connecticut. J. Entomol. Sci. 28: 393- 403.

Stoner, K. A. (1997). Influences of mulches on the colonization by adults and survival of larvae of the Colorado potato beetle (Coleoptera: Chrysomelidae) in eggplant. J. Entomol. Sci. 32: 7-16.

Tisdale, Samuel, L. and Werner, L., Nelson. (1995). Soil Fertility and Fertilizers. Macmillan Publishing Co, Inc., New York.

Tom, C. (2002). 'Pests of pepper'. Cooporarive extensive service, North Carolina, USA.

Walker, R. F., Mclaughlin, S. B. (1989). Black polythene mulch improves growth of plantation-grown loblolly pine and yellow-poplar. New Forests, 3: 265-274.

Zehnder, G. W., Hough-Goldstein, J. (1990). Colorado potato beetle (Coleoptera: Chrysomelidae) population development and effect on yield of potatoes with and without straw mulch. J. Econ. Entomol. 83: 1982-1987. 